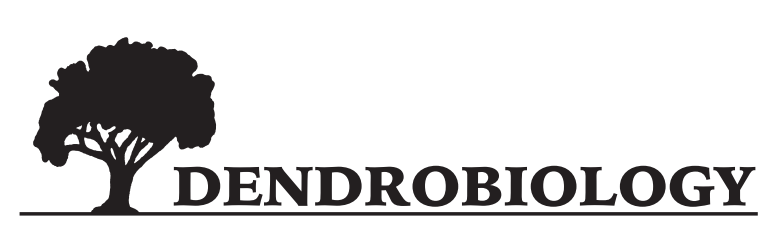

2016, vol. 75, 87-97

http://dx.doi.org/10.12657/denbio.075.009

Hanna Kwaśna, Monika Małecka, Zbigniew Sierota, Tomasz Jaworski

\title{
Effects of sawdust amendment on forest soil fungal community and infestation by cockchafers
}

Received: 1 January 2015; Accepted: 19 January 2016

\begin{abstract}
Effects of Scots pine wood amendment on the fungal community in forest soil infested with cockchafers and foraged or non-foraged by wild boars and hares were investigated. We hypothesized that sawdust amendment would increase the abundance of entomopathogenic and insect-associated species effective in cockchafer predation. The soil dilution method and morphotyping were used for fungal isolation and identification in order to quantify and qualify the viable components of the microbiota that are important for evaluating soil functions. There was usually increased abundance and decreased diversity of soil fungi one year after sawdust amendment. Application of pine sawdust more often increased than decreased the abundance of some insect-associated fungi or dermatophytes and keratinophilic species and decreased the number of cockchafer larvae. Abundance of Geomyces pannorum, Mortierella spp. + M. luteus, Pseudogymnoascus roseus, Tolypocladium inflatum and Trichoderma koningii increased, at least locally, whilst Chrysosporium merdarium, Penicillium spp. (including the most common P. citrinum, P. daleae and P. janczewskii), Sporothrix schenckii and Trichoderma spp. decreased. Application of pine sawdust under roots of 1-year-old Scots pine seedlings significantly increased the abundance of Phoma + Pyrenochaeta spp. in neighbouring soil, thus increasing the risk from Phoma blight. Trichoderma strigosum was among the dominants (frequency $>5 \%$ ). Another six and two Trichoderma species were among the subdominants (frequency 1-5\%) and subrecedents (frequency $<1 \%$ ), respectively. Dermatophytes, coprophilous and keratinophilic species, e.g. Cephalotrichum, Chrysosporium merdarium or S. schenckii, occurred only or mostly in foraged plots. The altered communities resulting from pine sawdust amendment may contribute to biological control of the cockchafer larvae.
\end{abstract}

Keywords: cockchafers, forest soil, fungal communities, sawdust amendment

Addresses: H. Kwaśna, Poznań University of Life Sciences, Department of Forest Pathology, Wojska Polskiego 71c, 60-625 Poznań, Poland, e-mail: kwasna@up.poznan.pl M. Małecka, Z. Sierota, T. Jaworski, Forest Research Institute, Department of Forest Protection, Sękocin Stary, Braci Leśnej 3, 05-090 Raszyn, Poland Z. Sierota, University of Warmia-Mazury in Olsztyn, Department of Forestry and Forest Ecology, Pl. Łódzki 2, 10-727 Olsztyn, Poland

\section{Introduction}

Cockchafers are European beetles of the genus Melolontha. In the last 20 years the common cock- chafer (Melolontha melolontha L.) and the forest cockchafer ( $M$. hippocastani Fabr.) were found to occur in central Europe on more than 200000 hectares, causing considerable losses in plant and wood pro- 
duction (Keller \& Brennen, 2005; Keller \& Zimmermann, 2005; Malinowski, 2007; Oltean et al., 2010; Svestka, 2010).

In Poland, in 1995-2012, progressive increases in $M$. melolontha and M. hippocastani were reported in 15-120 000 ha of forests; particularly in central-eastern Poland. Severe damage in nurseries and plantations was observed in 175 forest districts on 31896 ha (Woreta, 2013). Restocking the infested areas by fill-planting or under-planting does not improve the condition of the forests.

Adult cockchafers injure the leaves and flowers of many deciduous trees, shrubs and herbaceous plants, but rarely cause any serious damage. However, their fat, white larvae, 40-45 mm long, feed on plant roots and this results in stunted growth, wilting, necrosis and premature shedding of leaves. A density of 5-40 beetles per $\mathrm{m}^{2}$ may cause up to $25 \%$ plant damage. Entire forest stretches may be defoliated. Cockchafers often occur on pedunculate oak (Quercus robur L.) and sessile oak (Q. petraea (Mattuschka) Liebl.), less often on leaves of Aesculus, Acer, Betula, Carpinus, Fagus, Populus, Salix and Sorbus and on needles of Larix, and occasionally on flowers of Abies, Picea and Pinus (Luterek \& Szmidt, 1997).

The cockchafer usually has a 3-year life cycle. After mating, the female lays 10-20 eggs in soil at 20 $\mathrm{cm}$ depth. The eggs hatch after 21 days and the larvae remain in the soil for two years before changing into adult beetles. The young larvae consume humus and small tender roots, mainly of grasses. The older larvae injure the roots of seedlings and young trees (Blum, 1985).

The current expansion of cockchafers may be a result of increased temperature (with global warming) and intensive forest management, i.e. deforestation over larger continuous areas (Niemczyk \& Neyko, 2009).

Until recently, cockchafer larvae were controlled directly by the use of soil-applied insecticides containing carbofuran, carbosulfan, chloropyrifos or diazinon. After recent EC regulations prohibited the use of chemicals in forest nurseries (EC No $1107 / 2009$ of the European Parliament) the recommendations for control of cockchafers include: (i) stimulation of growth of healthy and resistant plants by appropriate field tillage (summer ploughing of the soil, causing mechanical damage of larvae and their exposure to predation by birds); (ii) the use of high quality seeding and planting material for reforestation; (iii) correct choice of tree and bush grades; (iv) adequate watering and fertilizing; (v) annual or bi-annual fallowing; (vi) weed control; (vii) catching beetles with light traps (Woreta, 2015). Mechanical control of cockchafers is difficult and fallowing impossible in forests, where the alternative option is a more direct form of biological control.
Some entomopathogenic fungi, e.g. Beauveria bassiana (Bals.-Criv.) Vuill., B. brongniartii (Sacc.) Petch, Metarhizium anisopliae (Metschn.) Sorokīn and Tolypocladium species, entomopathogenic bacteria, e.g. Bacillus thuringiensis and Coccobacillus sp., microsporidia, e.g. Pleistophora melolonthae H. and Telohania sp., and nematodes may occur on all developmental stages of cockchafers, but especially on larvae and pupae (Shapiro-Ilan et al., 2002; Enkerli et al., 2004; Laengle et al., 2005; Lakatos \& Tóth, 2006; Łabanowska \& Bednarek, 2011).

The list of other insect-pathogenic or insect-associated fungi includes species of Absidia, Acremonium, Aspergillus Chaetomium, Cladosporium, Clonostachys, Fusarium, Geomyces, Lecanicillium, Mortierella, Mucor, Nomuraea, Paecilomyces, Penicillium, Phialophora, Pseudogymnoascus, Rhizopus, Talaromyces, Trichoderma and Williopsis (Visser et al., 1987; Gunde-Cimerman et al., 1998; Ali-Shtayeh et al., 2002; Deshmukh, 2002; Toledo et al., 2006; Domsch et al., 2007; Sun \& Liu, 2008; Sun et al., 2008). Sun and Liu (2008) recorded 46 species from 27 genera. Insect-associated fungi may be opportunistic pathogens, which occur on predisposed insects causing epizootics, or secondary colonizers which come next in fungal successions (Thomas et al. 2003; Sun \& Liu, 2008).

Fungal epizootics in soil insect populations are well documented and illustrated (Samson et al., 1988; Keller \& Zimmerman, 1989; Klingen \& Haukeland, 2006). Mechanisms of successful fungal pathogenesis include contact of conidia with the cuticle of the host insect, germination of conidia, growth of hyphae and production and transfer of enzymes and mycotoxins that suppress the host's immune system (e.g. beauverin, destruxins and efrapeptins produced, respectively, by B. bassiana, M. anisopliae and Tolypocladium) (Huxham et al., 1989; Hajek \& St. Leger, 1994; Mazet et al., 1994; Clarkson \& Charnley, 1996; Vilcinskas et al., 1997; Bandani et al., 2000; Hummel et al., 2002; Zimmermann, 2007).

Effective products based on $B$. brongniartii have been approved for use and are marketed in several European countries (including Austria, Italy and Switzerland). However, none of the strains currently used commercially is effective against larvae of $M$. melolontha and M. hippocastani. None of the commercial products has yet been approved for use in Poland.

The aim of the research was to study abundance, diversity, spatial and temporal distribution and effects of fungi, including insect-associated and dung-associated species, in forest soils infested with cockchafers, foraged by wild boars and hares and amended with Scots pine sawdust.

The sawdust application was intended, by causing changes in the physical and nutritional or other chemical properties of soil, to initiate and stimulate microbiological changes, which may contribute to bi- 
ological control of cockchafers. The hypothesis that sawdust amendment would increase the density of insect-associated fungi, including species pathogenic to cockchafers, results from their cellulolytic and xylanolytic abilities and preferences for wood (Bääth \& Soderström, 1980; Svarstad et al., 2000; Domsch et al., 2007). Positive effects of pine sawdust as a stimulant of changes in soil microbiology, and its biochemical and phytopathological consequences, have been reported previously (Kwaśna et al., 2000, 2001; Grenni et al., 2012). Pine sawdust as an amendment to fallow soil stimulated the growth of some antagonists of the forest pathogens Armillaria and Heterobasidion spp., and increased the population of nematodes, including predatory species.

\section{Material and methods}

\section{Site description}

The studies were carried out in two clear-felled locations (LA and LB) in Lubartów Forest District (south-east Poland, $22^{\circ} 38^{\prime} \mathrm{E}, 51^{\circ} 28^{\prime} \mathrm{N}$ ). The soil of both locations was seriously infested with the common cockchafer (M. melolontha). The LA location (division 201c) was not fenced and was foraged by wild boars (Sus scrofa L.) and European hare (Lepus europaeus Pallas). The area LB (division 159a) was fenced and was non-foraged. In May 2012, in each location, a $640 \mathrm{~m}^{2}$ area was divided into four blocks of $160 \mathrm{~m}^{2}$. Each block was sub-divided into three linear plots $\left(40 \mathrm{~m} \times 1.2 \mathrm{~m}=48 \mathrm{~m}^{2}\right)$ : T1 plot, T2 plot and control plot. In T1 plots, $7.5 \mathrm{dm}^{3}$ of fresh Scots pine sawdust was spread on the surfaces of $1 \mathrm{~m} \times 0.4$ $\mathrm{m}$ areas and mixed into the topsoil to a depth of 20 $\mathrm{cm}$ by rotary cultivator. One-year-old Pinus sylvestris L. seedlings were planted in rows with $1.2 \mathrm{~m} \times 0.6 \mathrm{~m}$ spacing immediately after treatment. In T2 plots, 0.3 $\mathrm{dm}^{3}$ of fresh Scots pine sawdust was placed under the roots of each of the 1-year-old P. sylvestris seedlings while planting. In control plots there was no sawdust amendment and Scots pine seedlings were planted into non-treated soil.

The soil was sandy-loam ( $11.8 \%$ clay, $13.6 \%$ silt, $74.5 \%$ sand) with characteristics given in Table 1 . Weather conditions are presented in Table 2. In 2012 there was a dry spring, hot summer and wet autumn, and in 2013 a severe winter $\left(-19.2^{\circ} \mathrm{C}\right.$ above ground in January).

\section{Collection of soil samples}

In May 2012 (before treatment) and in May 2013 (12 months after treatment), six 7.5-cm-diam. sub-samples (cores) of non-rhizosphere soil were collected from the A-B horizon (0-20 cm deep) (1) between two rows of pine seedlings in treatment $\mathrm{T} 1$, (2) under seedlings in treatment T2, and (3) between two rows of seedlings in the control, in each of the

Table 1. Characteristics of soils at Lubartów before treatment (May 2012) and after treatment (May 2013)

\begin{tabular}{|c|c|c|c|c|c|c|c|c|c|c|}
\hline Date & $\begin{array}{l}\text { Treat- } \\
\text { ment }\end{array}$ & $\begin{array}{c}\mathrm{pH} \text { in } \\
\mathrm{H}_{2} \mathrm{O}\end{array}$ & $\begin{array}{l}\mathrm{pH} \text { in } \\
\mathrm{KCl}^{1}\end{array}$ & $\mathrm{C}(\%)^{2}$ & $\mathrm{~N}(\%)^{3}$ & $\mathrm{C}: \mathrm{N}$ & $\begin{array}{c}\mathrm{P} \\
\left(\mathrm{mg} 100 \mathrm{~g}^{-1}\right)^{4} \\
\end{array}$ & $\begin{array}{c}\mathrm{K} \\
\left(\mathrm{mg} 100 \mathrm{~g}^{-1}\right)^{5} \\
\end{array}$ & $\begin{array}{c}\mathrm{Ca} \\
\left(\mathrm{mg} 100 \mathrm{~g}^{-1}\right)^{5} \\
\end{array}$ & $\begin{array}{c}\mathrm{Mg} \\
\left(\mathrm{mg} 100 \mathrm{~g}^{-1}\right)^{5}\end{array}$ \\
\hline \multicolumn{11}{|c|}{ Foraged by wild boar and hares (LA) } \\
\hline \multirow[t]{2}{*}{$\begin{array}{l}\text { May } \\
2012\end{array}$} & - & $4.91 b$ & $3.85 b$ & $2.31 \mathrm{~d}$ & $0.16 \mathrm{a}$ & $14.25 \mathrm{~d}$ & $2.46 c$ & $7.24 c$ & $19.77 c$ & $2.93 c$ \\
\hline & $\mathrm{T} 1$ & $4.70 \mathrm{a}$ & $3.70 \mathrm{a}$ & $2.11 \mathrm{c}$ & $0.15 \mathrm{a}$ & $14.10 c$ & $1.23 \mathrm{a}$ & $4.04 \mathrm{~b}$ & $17.0 \mathrm{~b}$ & $2.22 b$ \\
\hline \multirow{2}{*}{$\begin{array}{l}\text { May } \\
2013\end{array}$} & $\mathrm{~T} 2$ & $5.00 \mathrm{~b}$ & $4.00 \mathrm{c}$ & $1.36 \mathrm{a}$ & $0.10 \mathrm{a}$ & $13.20 \mathrm{a}$ & $1.69 b$ & $3.76 \mathrm{a}$ & $12.0 \mathrm{a}$ & $1.53 \mathrm{a}$ \\
\hline & $\begin{array}{l}\text { Con- } \\
\text { trol }\end{array}$ & $4.84 \mathrm{ab}$ & $4.80 \mathrm{~d}$ & $1.64 b$ & $0.12 \mathrm{a}$ & $13.30 \mathrm{~b}$ & $5.36 \mathrm{~d}$ & $14.69 \mathrm{~d}$ & $50.0 d$ & $5.79 \mathrm{~d}$ \\
\hline \multicolumn{2}{|c|}{$\mathrm{F}$} & 47.64 & 2406.25 & 2331.36 & 7.58 & 2906.25 & 34377.67 & 289015.58 & 2949915.58 & 35010.25 \\
\hline \multicolumn{2}{|c|}{$P$} & 0.0014 & 0.0000 & 0.0000 & 0.0398 & 0.0000 & 0.0000 & 0.0000 & 0.0000 & 0.0000 \\
\hline \multicolumn{11}{|c|}{ Non-foraged by wild boar and hares (LB) } \\
\hline \multirow[t]{2}{*}{$\begin{array}{l}\text { May } \\
2012\end{array}$} & - & $4.68 \mathrm{a}$ & $3.8 \mathrm{a}$ & $1.28 b$ & $0.09 a$ & $14.56 b$ & $1.03 \mathrm{bc}$ & $4.09 \mathrm{~d}$ & $9.1 \mathrm{c}$ & $1.34 \mathrm{c}$ \\
\hline & $\mathrm{T} 1$ & $5.00 c$ & $3.8 \mathrm{a}$ & $1.43 c$ & $0.10 \mathrm{a}$ & $14.70 \mathrm{c}$ & $1.11 \mathrm{c}$ & $3.60 c$ & $10.0 d$ & $1.31 \mathrm{c}$ \\
\hline \multirow{4}{*}{$\begin{array}{l}\text { May } \\
2013\end{array}$} & $\mathrm{~T} 2$ & $4.70 \mathrm{a}$ & $3.9 b$ & $1.10 \mathrm{a}$ & $0.08 \mathrm{a}$ & $13.80 \mathrm{a}$ & $0.93 a$ & $2.56 \mathrm{~b}$ & $5.0 \mathrm{a}$ & $0.64 \mathrm{a}$ \\
\hline & $\begin{array}{l}\text { Con- } \\
\text { trol }\end{array}$ & $4.80 \mathrm{~b}$ & $3.8 \mathrm{a}$ & $1.29 \mathrm{~b}$ & $0.09 a$ & $13.80 \mathrm{a}$ & $0.95 \mathrm{ab}$ & $2.28 \mathrm{a}$ & $8.0 \mathrm{~b}$ & $0.78 b$ \\
\hline & $\mathrm{F}$ & 214.33 & 25.00 & 183.00 & 0.96 & 2329.00 & 67.67 & 7299.58 & 15920.98 & 1245.58 \\
\hline & $P$ & 0.0001 & 0.0047 & 0.0001 & 0.4941 & 0.0000 & 0.0007 & 0.0000 & 0.0000 & 0.0000 \\
\hline
\end{tabular}

1 - analysed with potentiometer according to norm PN-ISO 103390:1997

2 - analysed chemically according to norm PN-ISO 10694:2002

3 - analysed chemically according to norm PN-13878:2002

4 - analysed chemically with method of Egner-Riehm

5 - analysed chemically according to procedure PB-05 ed.2

a,b,c - different letters indicate statistically significant difference according to one-way ANOVA at $\mathrm{P} \leq 0.01$.

T1 - sawdust mixed into topsoil; T2 - sawdust placed under roots; Control - no sawdust. 
Table 2. Temperature and rainfall at Lubartów in 2012 and 2013 (until May)

\begin{tabular}{lcc}
\hline & 2012 & 2013 \\
\hline Air temperature $\left({ }^{\circ} \mathrm{C}\right)$ & minimal -7.5 (February), & minimal -4.1 (January), \\
maximal 14.8 (May) & maximal 20.8 (July) & -19.2 (January) \\
Minimal temperature of air above ground $\left({ }^{\circ} \mathrm{C}\right)$ & -23.9 (February) & -2.2 (January) \\
Minimal temperature of topsoil at the depth $5 \mathrm{~cm}\left({ }^{\circ} \mathrm{C}\right)$ & -7.4 (February) & minimal 19.3 (February), \\
Rainfall $(\mathrm{mm})$ & maximal 87.1 (October) & maximal 105.6 (May) \\
\hline
\end{tabular}

four randomized blocks. The sub-samples from each plot were bulked together and mixed by rotating for $10 \mathrm{~h}$.

\section{Isolation and identification of fungi}

Soil fungi were isolated using the soil-dilution method: $1 \mathrm{~g}$ of soil was diluted in $149 \mathrm{~g}$ of sterile quartz sand and $0.02 \mathrm{~g}$ of the mixture was put into a Petri dish and covered with liquid $\left(50^{\circ} \mathrm{C}\right)$ Johnson-Martin's agar (JMA; glucose $10 \mathrm{~g} \mathrm{l}^{-1}$, peptone 5 $\mathrm{g} \mathrm{l}^{-1}, \mathrm{KH}_{2} \mathrm{PO}_{4} 1 \mathrm{~g} \mathrm{l}^{-1}, \mathrm{MgSO}_{4} .7 \mathrm{H}_{2} \mathrm{O} 0.5 \mathrm{~g} \mathrm{l}^{-1}$, rose Bengal $0.03 \mathrm{~g} \mathrm{l}^{-1}$, aureomycin $0.0025 \mathrm{~g} \mathrm{l}^{-1}$, agar $20 \mathrm{~g} \mathrm{l}^{-1}$ ). Eight replicates (Petri dishes) were made for each plot (= 32 Petri dishes per treatment). All plates were incubated for 20 days at $25^{\circ} \mathrm{C}$.

All colonies on each plate were examined macroand microscopically and distinguished on the basis of colour, growth rate, hyphal characteristics and sporulation. Colonies of each species were counted and representatives of fungi were identified by morphotyping on potato dextrose agar (PDA; Difco PDA 39 $\mathrm{g}^{-1}, \mathrm{pH}$ 5.5), synthetic nutrient agar (SNA; $\mathrm{KH}_{2} \mathrm{PO}_{4}$ $1 \mathrm{~g} \mathrm{l}^{-1}, \mathrm{KNO}_{3} 1 \mathrm{~g} \mathrm{l}^{-1}, \mathrm{MgSO}_{4} \cdot 7 \mathrm{H}_{2} \mathrm{O} 0.5 \mathrm{~g} \mathrm{l}^{-1}, \mathrm{KCl}^{2} 0.5$ $\mathrm{g} \mathrm{l}^{-1}$, glucose $0.2 \mathrm{~g} \mathrm{l}^{-1}$, sucrose $0.2 \mathrm{~g} \mathrm{l}^{-1}$, agar $20 \mathrm{~g} \mathrm{l}^{-1}$ ), Czapek yeast autolysate agar (CYA; sucrose $30 \mathrm{~g} \mathrm{l}^{-1}$, powdered yeast extract $5 \mathrm{~g} \mathrm{l}^{-1}, \mathrm{KH}_{2} \mathrm{PO}_{4} 1 \mathrm{~g} \mathrm{l}^{-1}$, Czapek concentrate $10 \mathrm{ml} \mathrm{l}^{-1}$, agar $15 \mathrm{~g} \mathrm{l}^{-1}$ ) and $2 \%$ malt extract agar (MEA; powdered malt extract $20 \mathrm{~g} \mathrm{l}^{-1}$, glucose $20 \mathrm{~g} \mathrm{l}^{-1}$, peptone $1 \mathrm{~g} \mathrm{l}^{-1}$, agar $\left.20 \mathrm{~g} \mathrm{l}^{-1}\right)$. Identification was made according to Barron and Peterson (1968), Pitt (1979), Klich and Pitt (1992) and Domsch et al. (2007).

Abundance of fungi was defined as the number of colony forming units $(c f u)$ in a sample. Diversity was defined as the number of species in a sample. A species, or group of related species of fungi was considered as: (i) dominant, with frequency $>5 \%$, (ii) subdominant, with frequency $1-5 \%$, or (iii) subrecedent, with frequency $<1 \%$, at least in one treatment (Tischler, 1949).

\section{Collection of cockchafer larvae}

Soil samples were collected before treatment (October 2011) and 5 and 12 months after treatment, in October 2012 (during pupation) and in May 2013 (when adults appeared). Small number of cockchaf- ers collected in 2012 necessitated an increase in sampling locations in 2013 when samples were taken (1) between two rows, (2) under seedlings and (3) between seedlings, in the row. In each combination six samples located $20 \mathrm{~m}$ apart were analysed. Each consisted of $0.15 \mathrm{~m}^{3}$ of topsoil taken from the A-B horizon (0-30 cm deep) in an area $1 \mathrm{~m} \times 0.4 \mathrm{~m}$. Soil was sieved with a 5-mm-diam. sieve and the cockchafer larvae were counted on its surface. Mean values were calculated.

\section{Assessment of Pinus sylvestris seedling mortality}

One year after treatment (May 2013) all P. sylvestris seedlings were assessed for the presence of disease symptoms or mechanical injuries. Dead or dying seedlings, often with grub injuries on roots, were counted. Mortality was defined as the proportion of dead seedlings in the total number of seedlings planted.

\section{Statistics}

Differences in soil chemical properties, numbers of cockchafer larvae and numbers of dead P. sylvestris seedlings at the two locations after different treatments were analysed using one-way analysis of variance (ANOVA), with treatment or location as the variable, and the two sites being analysed separately, using Statgraphics ${ }^{\mathrm{TM}}$ Centurion (Statpoint Technologies, Inc. Warrenton, VA, USA). Abundances and diversity of fungi from two different treatments were analysed by $\chi^{2}$ - test.

Diversity within and between fungal communities was compared using diversity indices calculated for each community (Magurran, 1988). Species richness was indicated by the total number of species in the community by Margalef's index (DMg) and by Shannon's diversity index $\left(\mathrm{H}^{\prime}\right)$. Evenness and dominance were indicated by Shannon's evenness index (E), Simpson's index (D) and Berger-Parker's index (d). The similarity between fungal communities in two systems was determined by calculating the qualitative Sorensen's similarity index $(\mathrm{CN})$.

Relationships between (1) C (\%), N (\%), P (mg $\left.100 \mathrm{~g}^{-1}\right), \mathrm{K}\left(\mathrm{mg} 100 \mathrm{~g}^{-1}\right)$, Ca $\left(\mathrm{mg} 100 \mathrm{~g}^{-1}\right)$ or $\mathrm{Mg}(\mathrm{mg}$ 
Table 3. Abundance (number of colony forming units per treatment) of fungal taxa recorded in Lubartów soils

\begin{tabular}{|c|c|c|c|c|c|c|c|c|c|}
\hline \multirow{4}{*}{ No. } & \multirow{4}{*}{ Taxon } & \multicolumn{4}{|c|}{ Foraged by wild boars and hares } & \multicolumn{4}{|c|}{ Non-foraged by wild boars and hares } \\
\hline & & \multicolumn{2}{|c|}{$\begin{array}{l}\text { May } \\
2012\end{array}$} & \multicolumn{2}{|c|}{ May 2013} & \multirow{2}{*}{$\begin{array}{l}\text { May } \\
2012 \\
-\end{array}$} & \multicolumn{3}{|c|}{ May 2013} \\
\hline & & - & $\mathrm{T} 1$ & $\mathrm{~T} 2$ & Control & & $\mathrm{T} 1$ & $\mathrm{~T} 2$ & Control \\
\hline & & \multicolumn{8}{|c|}{ Dominants (with frequency $>5 \%$ ) } \\
\hline \multicolumn{10}{|c|}{ Zygomycota } \\
\hline 1. & $\begin{array}{l}\text { Mortierella parvispora Linnem. + M. verticillata Linnem. } \\
+ \text { Mortierella sp. }+ \text { Mucor luteus Linnem. ex Wrzosek } \\
\text { Ascomycota }\end{array}$ & 2 & 1a & 2 & $6 \mathrm{~b}$ & Oa & $28 \mathrm{~b}$ & $19 \mathrm{c}$ & $7 \mathrm{~d}$ \\
\hline 2. & $\begin{array}{l}\text { Cephalotrichum nanum (Ehrenb.) S. Hughes + C. stemo- } \\
\text { nitis (Pers.) Nees }\end{array}$ & Oa & $3 b$ & $103 c$ & $36 \mathrm{~d}$ & 0 & 0 & 0 & 0 \\
\hline 3. & Chrysosporium merdarium (Ehrenb.) J.W. Carmich & $30 \mathrm{a}$ & $5 b$ & $4 c$ & $102 d$ & $7 a$ & $10 \mathrm{~b}$ & Oc & $64 d$ \\
\hline 4. & Geomyces pannorum (Link) Sigler \& J.W. Carmich. & $34 \mathrm{a}$ & $227 b$ & $191 c$ & $41 \mathrm{a}$ & $60 \mathrm{a}$ & $244 b$ & $42 c$ & $60 \mathrm{ac}$ \\
\hline 5. & $\begin{array}{l}\text { Penicillium aculeatum Raper \& Fennell }+ \text { P. chrysogenum } \\
\text { Thom }+ \text { P. citreonigrum Dierckx }+ \text { P. citrinum Thom }+ \\
\text { P. commune Thom }+ \text { P. corylophilum Dierckx }+ \text { P. daleae } \\
\text { Zaleski }+ \text { P. expansum Link }+ \text { P. granulatum Bainier }+ \\
\text { P. janczewskii Zaleski }+ \text { P. janthinellum Biourge }+ \text { P. } \\
\text { raistrickii G. Sm. + P. spinulosum Thom }+ \text { P. waks- } \\
\text { manii Zaleski }+ \text { Talaromyces islandicus (Sopp) Samson, } \\
\text { Yilmaz, Frisvad \& Seifert }+ \text { T. pinophilus (Hedgc.) } \\
\text { Samson, Yilmaz, Frisvad \& Seifert }+ \text { T. purpurogenus } \\
\text { (Stoll) Samson, Yilmaz, Frisvad \& Seifert }+ \text { T. verrucu- } \\
\text { losus (Peyronel) Samson, Yilmaz, Frisvad \& Seifert }\end{array}$ & $286 a$ & $11 b$ & $91 \mathrm{c}$ & $97 c$ & $126 \mathrm{a}$ & $49 b$ & $99 c$ & $188 \mathrm{~d}$ \\
\hline 6. & $\begin{array}{l}\text { Phoma eupyrena Sacc. }+ \text { P. leveillei Boerema \& G.J. } \\
\text { Bollen }+ \text { Pyrenochaeta unguis-hominis Punith. \& M.P. } \\
\text { English }\end{array}$ & Oa & 1a & $14 \mathrm{~b}$ & $4 a$ & $0 \mathrm{a}$ & Oa & $10 \mathrm{~b}$ & $0 \mathrm{a}$ \\
\hline 7. & Pseudogymnoascus roseus Raillo & Oa & $1251 b$ & $455 c$ & $74 \mathrm{~d}$ & $4 a$ & $402 b$ & $131 \mathrm{c}$ & 200d \\
\hline 8. & Sporothrix schenckii Hektoen \& C.F. Perkins & $15 \mathrm{a}$ & $2 b$ & $16 c$ & $118 \mathrm{~d}$ & $8 a$ & $2 \mathrm{ac}$ & $12 \mathrm{bd}$ & $2 \mathrm{ae}$ \\
\hline \multirow[t]{2}{*}{9.} & $\begin{array}{l}\text { Trichoderma atroviride } \text { P. Karst. + T. citrinoviride Bissett } \\
+ \text { T. harzianum Rifai }+ \text { T. koningii Oudem. }+ \text { T. longipilis } \\
\text { Bissett }+ \text { T. polysporum (Link) Rifai }+ \text { T. pubescens } \\
\text { Bissett }+ \text { T. strigosum Bissett }+ \text { T. viride Pers. }\end{array}$ & $55 \mathrm{a}$ & $\mathrm{Ob}$ & $51 \mathrm{c}$ & $15 \mathrm{~d}$ & $59 a$ & $17 \mathrm{~b}$ & $14 \mathrm{c}$ & $36 \mathrm{~d}$ \\
\hline & & \multicolumn{8}{|c|}{ Subdominant (with frequency $1-5 \%$ ) } \\
\hline 10. & Candida albicans (C.P. Robin) Berkhout & 0 & 1 & 0 & 8 & 0 & 3 & 1 & 0 \\
\hline & $\begin{array}{l}\text { Chaetosphaeria vermicularioides (Sacc. \& Roum.) W. } \\
\text { Gams \& Hol.-Jech. }\end{array}$ & 0 & 0 & 0 & 0 & 0 & 0 & 0 & 10 \\
\hline 12. & Cladosporium cladosporioides (Fresen.) G.A. de Vries & $0 \mathrm{a}$ & $1 \mathrm{a}$ & $0 \mathrm{a}$ & $18 \mathrm{~b}$ & 0 & 0 & 0 & 1 \\
\hline 13. & Clonostachys candelabrum (Bonord.) Schroers & 6 & 0 & 0 & 0 & 3 & 0 & 0 & 0 \\
\hline & $\begin{array}{l}\text { Exophiala jeanselmei (Langeron) McGinnis \& A.A. } \\
\text { Padhye }\end{array}$ & 0 & 0 & 7 & 0 & 0 & 0 & 5 & 0 \\
\hline 15. & Hormiactis candida Höhn. & 0 & 2 & 5 & 0 & $0 \mathrm{a}$ & $17 \mathrm{~b}$ & $0 \mathrm{a}$ & $11 b$ \\
\hline 16. & Humicola grisea Traaen & 1 & 0 & 0 & 7 & 0 & 0 & 0 & 1 \\
\hline 17. & Leptosphaeria coniothyrium (Fuckel) Sacc. & 0 & 0 & 0 & 0 & 5 & 0 & 0 & 0 \\
\hline & $\begin{array}{l}\text { Myrmecridium schulzeri (Sacc.) Arzanlou, W. Gams \& } \\
\text { Crous }\end{array}$ & 0 & 0 & 2 & 1 & 0 & 0 & 5 & 0 \\
\hline 20. & $\begin{array}{l}\text { Oidiodendron echinulatum G.L. Barron }+ \text { O. chla- } \\
\text { mydosporicum Morrall }+ \text { O. griseum Robak }+ \text { O. tenuissi- } \\
\text { mum (Peck) S. Hughes }\end{array}$ & 2 & 0 & 0 & 6 & 4 & 2 & 4 & 0 \\
\hline 21. & Paraconiothyrium fuckelii (Sacc.) Verkley \& Gruyter & 2 & 0 & 0 & 1 & 6 & 1 & 9 & 15 \\
\hline & Tolypocladium inflatum W. Gams & 0 & 1 & 0 & 0 & 3 & $10 \mathrm{a}$ & 0 & $\mathrm{Ob}$ \\
\hline & Truncatella truncata (Lév.) Steyaert & 2 & 0 & 0 & 0 & 4 & 0 & 0 & 0 \\
\hline & $\begin{array}{l}\text { Total abundance (including subrecedents) - number } \\
\text { of colony forming units ( } f f u \text { in a sample }\end{array}$ & $441 \mathrm{a}$ & $1512 b$ & $969 c$ & $556 \mathrm{~d}$ & $295 \mathrm{a}$ & $787 \mathrm{~b}$ & $364 c$ & $604 d$ \\
\hline & Diversity - number of species in a sample & 25 & $19 a$ & 30 & $38 \mathrm{~b}$ & 26 & 22 & 29 & 27 \\
\hline
\end{tabular}

Subrecedents (with frequency <1\%) included Aphanocladium album (Preuss) W. Gams, Aspergillus kanagawaensis Nehira, A. repens (Corda) Sacc., A. tardus Bissett \& Widden, Aspergillus sp., Beauveria bassiana (Bals.-Criv.) Vuill., Chaetomium globosum Kunze, Cylindrocarpon didymum (Harting) Wollenw., C. obtusisporum (Cooke \& Harkn.) Wollenw., Davidiella macrocarpa Crous, K. Schub. \& U. Braun, Dicoccum asperum (Corda) Sacc., Epicoccum nigrum Link, Fusicolla merismoides (Corda) Gräfenhan, Seifert \& Schroers, Humicola fuscoatra Traaen, Mammaria echinobotryoides Ces., Metarhizium anisopliae (Metschn.) Sorokīn, Myceliophthora thermophila (Apinis) Oorschot, Paecilomyces carneus (Duché \& R. Heim) A.H.S. Br. \& G. Sm., Papulaspora nishigaharanus Ts. Watan, Pochonia bulbillosa (W. Gams \& Malla) Zare \& W. Gams, Sarocladium kiliense (Grütz) Summerb., Scolecobasidium constrictum E.V. Abbott, Trichocladium opacum (Corda) S. Hughes, Verticillium chlamydosporium Goddard, Wardomyces humicola Hennebert \& G.L. Barron.

a,b,c,d - different letters indicate statistically significant difference according to $\chi^{2}$ test at $\mathrm{P} \leq 0.001$ or $\mathrm{P} \leq 0.05$.

T1 - sawdust mixed into topsoil; T2 - sawdust placed under roots; Control - no sawdust. 
$100 \mathrm{~g}^{-1}$ ) content in foraged or non-foraged soil and total abundance (number) of fungi, abundance of the frequent taxa, i.e. P. roseus, Penicillium and Trichoderma, number of larvae or number of dead pine seedlings in May 2013 and (2) abundance of fungi and number of larvae were estimated with Pearson's correlation coefficient. There were 73 tests in total.

\section{Results}

\section{Changes in chemical properties of soils after sawdust amendment}

Application of sawdust amendment changed the chemical properties of forest soils. Spreading sawdust on the surface of the soil and mixing it with the topsoil (T1) resulted in: (1) increase in $\mathrm{C}$ and $\mathrm{N}$ content and $\mathrm{C}: \mathrm{N}$ ratio, and decrease in $\mathrm{pH}$ and $\mathrm{P}, \mathrm{K}$, $\mathrm{Ca}$ and $\mathrm{Mg}$ content in foraged soil; (2) increase in $\mathrm{pH}$ and in $\mathrm{C}, \mathrm{N}, \mathrm{P}, \mathrm{K}, \mathrm{Ca}$ and $\mathrm{Mg}$ content and $\mathrm{C}: \mathrm{N}$ ratio in non-foraged soil (Table 1). Placing sawdust under roots of seedlings (T2) resulted in: (1) change in $\mathrm{pH}$; (2) decrease in C, N, P, Ca and Mg content in foraged and non-foraged soils.

\section{Fungal community structure}

A total of 81 fungal species was recorded in non-rhizosphere soil, in two locations (foraged-LA, and non-foraged-LB), before and after amendment with Scots pine sawdust. Forty-one species occurred at both locations. Twenty-six species occurred only in LA soil and 14 species occurred only in LB soil. There were nine dominant species or groups of related species, 13 subdominant and 25 subrecedent species (Table 3 ). There was a significantly greater total abundance of fungi (in LA and partially in LB plots) and decreased diversity of fungi (in LA, T1 plot) one year after sawdust amendment.
Two coprophilous and keratinophilic species (Cephalotrichum nanum and C. stemonitis), three entomopathogenic species (B. bassiana, M. anisopliae and Tolypocladium inflatum) and some insect-associated species (Aspergillus spp., Chaetomium globosum, Cladosporium cladosporoides, Geomyces pannorum, Mortierella spp., Mucor luteus, Paecilomyces carneus, Penicillium chrysogenum, P. citrinum, Pseudogymnoascus roseus and Trichoderma koningii) were recorded (Petch, 1937; Visser et al., 1987; Marshall, 1998; Del Frate \& Caretta, 1990; Deshmukh, 2002; Ali et al., 2013; Domsch et al., 2007). Beauveria brongniartii, which is the most common and important natural enemy of M. melolontha, was not detected (Dolci et al., 2006).

Only C. nanum + C. stemonitis, G. pannorum, Mortierella spp. + Mucor luteus, $P$. roseus and T. koningii were among the dominants (frequency $>5 \%$ ). Tolypocladium inflatum was subdominant (frequency 1-5\%) and $B$. bassiana, M. anisopliae and P. carneus were subrecedent (frequency $<1 \%$ ).

Pine sawdust amendment usually increased significantly the abundance of $G$. pannorum and $P$. roseus, and decreased the abundance of Ch. merdarium and Penicilium spp. In foraged plots, pine sawdust amendment significantly increased the abundance of Cephalotrichum spp. and Trichoderma spp. (in T2) and decreased the abundance of $S$. schenckii. In non-foraged plots, sawdust amendment significantly increased the abundance of Mortierella spp. and decreased the abundance of Trichoderma. Application of pine sawdust under roots of 1-year-old Scots pine seedlings significantly increased the abundance of three Phoma and Pyrenochaeta species. Foraging by wild boars and hares locally increased the abundance of C. nanum + C. stemonitis, Chrysosporium merdarium and Sporothrix schenckii.

The most abundant Penicillium and Trichoderma species were $P$. citrinum, $P$. daleae, $P$. janczewskii and T. strigosum. Cephalotrichum nanum was more abundant than C. stemonitis.

Table 4. Diversity indices for fungi from soil foraged and non-foraged by wild boars and hares

\begin{tabular}{|c|c|c|c|c|c|c|c|c|}
\hline \multirow{3}{*}{ Index } & \multicolumn{4}{|c|}{ Foraged (LA) } & \multicolumn{4}{|c|}{ Non-foraged (LB) } \\
\hline & May 2012 & May 2013 & May 2013 & May 2013 & May 2012 & May 2013 & May 2013 & May 2013 \\
\hline & - & $\mathrm{T} 1$ & $\mathrm{~T} 2$ & Control & - & $\mathrm{T} 1$ & $\mathrm{~T} 2$ & Control \\
\hline & \multicolumn{8}{|c|}{ Species richness indices } \\
\hline Margalef's index (DMg) & 3.94 & 2.45 & 4.21 & 5.85 & 4.39 & 3.14 & 4.74 & 4.06 \\
\hline \multirow[t]{2}{*}{ Shannon's diversity index (H') } & 2.25 & 0.57 & 1.83 & 2.54 & 2.44 & 1.35 & 2.25 & 2.07 \\
\hline & \multicolumn{8}{|c|}{ Evenness or dominance indices } \\
\hline Shannon's evenness index (E) & 0.70 & 0.19 & 0.54 & 0.69 & 0.75 & 0.43 & 0.66 & 0.62 \\
\hline Simpson's index (D) & 0.16 & 0.71 & 0.27 & 0.28 & 0.14 & 0.36 & 0.18 & 0.17 \\
\hline \multirow[t]{2}{*}{ Berger-Parker's index (d) } & 0.33 & 0.83 & 0.47 & 0.21 & 0.26 & 0.51 & 0.36 & 0.33 \\
\hline & \multicolumn{4}{|c|}{0.27} & \multicolumn{3}{|c|}{0.46} & \\
\hline \multirow[t]{2}{*}{ Sorensen qualitative similarity index (CN) } & \multicolumn{4}{|c|}{0.51} & \multicolumn{3}{|c|}{0.55} & \\
\hline & \multicolumn{4}{|c|}{0.53} & \multicolumn{4}{|c|}{0.42} \\
\hline
\end{tabular}

T1 - sawdust mixed into topsoil; T2 - sawdust placed under roots; Control - no sawdust. 
Table 5. Number of cockchafer larvae in soils at Lubartów in October 2011 (before treatment) and in October 2012 and May 2013 (after treatment)

\begin{tabular}{|c|c|c|c|c|c|}
\hline \multirow{2}{*}{ Date } & \multirow{2}{*}{ Treatment } & \multicolumn{4}{|c|}{ Mean number of cockchafer larvae in $0.15 \mathrm{~m}^{3}$ of topsoil } \\
\hline & & Mean & Between rows & Under seedlings & Between seedlings, in the row \\
\hline \multicolumn{6}{|c|}{ Foraged by wild boars and hares (LA) } \\
\hline October 2011 & & $16 \mathrm{c}$ & & & \\
\hline October 2012 & & $9 \mathrm{ab}$ & & & \\
\hline \multirow[t]{5}{*}{ May 2013} & $\mathrm{~T} 1$ & $4.1 \mathrm{a}$ & $4.1 \mathrm{a}$ & $4.1 \mathrm{a}$ & $4.1 \mathrm{a}$ \\
\hline & $\mathrm{T} 2$ & $9.0 \mathrm{ab}$ & $8.4 \mathrm{~b}$ & $8.3 \mathrm{~b}$ & $10.4 \mathrm{~b}$ \\
\hline & Control & $11.8 \mathrm{bc}$ & $10.4 \mathrm{c}$ & $20.9 c$ & $4.1 \mathrm{a}$ \\
\hline & $\mathrm{F}$ & 46.83 & 1036.33 & 7644.0 & 1323.0 \\
\hline & $P$ & 0.0004 & 0.0001 & 0.0000 & 0.0000 \\
\hline \multicolumn{6}{|c|}{ Non-foraged by wild boars and hares (LB) } \\
\hline October 2011 & & $35 \mathrm{~d}$ & & & \\
\hline October 2012 & & $9 a$ & & & \\
\hline \multirow[t]{5}{*}{ May 2013} & $\mathrm{~T} 1$ & $13.3 \mathrm{ab}$ & $14.7 \mathrm{~b}$ & $20.9 a$ & $6.3 \mathrm{a}$ \\
\hline & $\mathrm{T} 2$ & $20.1 c$ & $16.6 c$ & $31.3 \mathrm{~b}$ & $12.5 \mathrm{~b}$ \\
\hline & Control & $17.4 \mathrm{bc}$ & $10.4 \mathrm{a}$ & $35.4 \mathrm{c}$ & $6.3 a$ \\
\hline & $\mathrm{F}$ & 341.53 & 1009.0 & 5587.0 & 1281.33 \\
\hline & $P$ & 0.0000 & 0.0001 & 0.0000 & 0.0000 \\
\hline
\end{tabular}

Different letters indicate a statistically significant difference according to one-way ANOVA at $\mathrm{P} \leq 0.01$.

T1 - sawdust mixed into topsoil; T2 - sawdust placed under roots; Control - no sawdust.

No correlation was observed between C, N, P, K, $\mathrm{Ca}$ or $\mathrm{Mg}$ content in soil and total abundance of fungi. There were positive correlations between $\mathrm{C}$ and $\mathrm{N}$ content and abundance of $P$. roseus $(r=0.80$ and 0.78 , $P \leq 0.001)$, and weak negative correlations between $\mathrm{C}$ and $\mathrm{N}$ content and abundance of Penicillium spp. $(r$ $=-0.65$ and $-0.66, P \leq 0.001)$ and Trichoderma spp. $(r=-0.53$ and $-0.55, P \leq 0.001)$.

Diversity of Fungi in microbial communities, measured as number of species, was mostly similar among treatments (Table 3). In the foraged locations there was significantly less diversity immediately after mixing sawdust with topsoil than in the control. The relatively small number of fungal taxa and the infrequent occurrence of many of these taxa resulted in relatively small diversity indices based on species richness $(\mathrm{DMg})$ and proportional abundance of species ( $\mathrm{H}^{\prime}$, Table 4). Sawdust amendment, particularly when it was mixed with the topsoil, decreased species richness and species abundance. The dominance of single taxa in communities resulted in small values for Shannon's evenness index (E) and high values for dominance indices ( $D$ and $d$ ). Evenness tended to be least, and dominance most, immediately after mixing sawdust with topsoil (May 2013, $\mathrm{T} 1)$. Sorensen's qualitative similarity index $(\mathrm{CN})$, used for comparing fungal communities in two treatments, suggests greater similarity (1) between sawdust treatments (May 2013, T1, T2) and control (C) in foraged than in non-foraged soil, (2) before sawdust treatment (May 2012) and after treatment (May 2013) in non-foraged than in foraged soil.

\section{Number of cockchafer larvae}

Before treatment (October 2011) the mean numbers of cockchafer larvae in foraged locations and non-foraged locations were 16 and 35 (Table 5). Application of pine sawdust usually significantly decreased the number of cockchafer larvae in both locations. One year after treatment the number of cockchafer larvae decreased to 4.1 and 9.0 in foraged locations and to 13.3 and 20.1 in non-foraged locations. Only in non-foraged locations after application of sawdust under roots of seedlings was the mean number of cockchafer larvae higher than in the

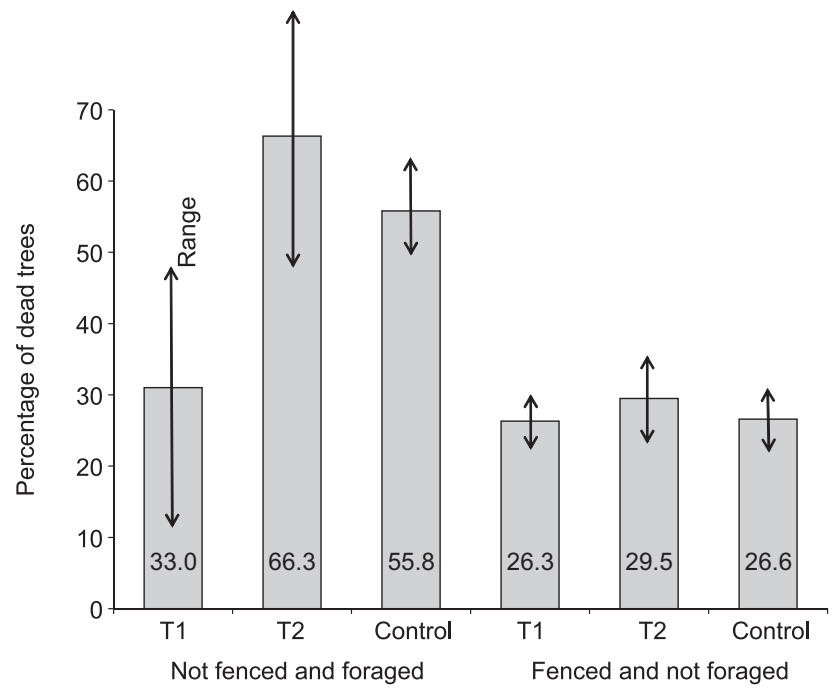

Fig. 1. Mortality (\%) of Scots pine seedlings in soils at Lubartów that were foraged by wild boars and hares or not foraged and amended with pine sawdust mixed into topsoil (T1) or under seedling roots (T2) 
control. Numbers of larvae were strongly negatively correlated with $\mathrm{C}$ and $\mathrm{N}$ content $(r-0.88$ and -0.90 , $P<0.0001)$ and total abundance of fungi $(r-0.91$, $P<0.0001)$.

\section{Pinus sylvestris seedling mortality}

One year after treatment (May 2013), the proportion of dead or dying $P$. sylvestris seedlings in foraged and non-foraged locations was $31.0-66.3 \%$ and 26.3-29.5\%, respectively (Fig. 1). Mortality of P. sylvestris seedlings on a single plot ranged from $11.1 \%$ to $81.7 \%$. There was a significant effect of location (LA > LB, one-way ANOVA, $\mathrm{F}=5.62, P=0.013$ ) but not of treatment $(\mathrm{T} 1=\mathrm{T} 2=\mathrm{C}$, one-way ANOVA, $\mathrm{F}=$ $1.03, P=0.378)$. There was a weak negative correlation between $\mathrm{P}, \mathrm{K}, \mathrm{Ca}$ and $\mathrm{Mg}$ content and number of dead seedlings $(r=-0.50$ to $-0.59, P<0.0001)$.

\section{Discussion}

Conservation biological control is a biological control strategy in which farming practices and environmental manipulations are adopted to enhance the living conditions for specific natural enemies of pests.

Pine sawdust amendment was used to alter the functional diversity of microorganisms in topsoil of a Scots pine plantation infested with cockchafers. We hypothesized that pine-wood amendment of soil would stimulate the growth of entomopathogenic fungi effective in biological control of cockchafer larvae. In agriculture, such an effect, i.e. increased population of entomopathogenic fungi, resulting from biological inputs, has been observed in soils on organic farms (Hummel et al., 2002; Klingen et al., 2002; Jabbour \& Barbercheck, 2009).

The topsoil (A-B horizon - 0-20 cm deep) was chosen for study because it is abundantly colonized by microorganisms, which find here nutrients present in root exudates, litter and amendment inputs, and because cockchafer larvae occur here.

The classical method, based on dilution plating and morphotyping, was chosen for evaluation of soil function based on abundance and known activity of viable components of the fungal communities. Profiling based on DNA sequences often tends to detect only the slow-growing, non-sporulating organisms whose activity is less recognized and understood and which have less obvious relevance in microbiological interactions (Kwaśna et al., 2008).

Application of pine sawdust (1) more often increased than decreased the total abundance of fungi as well as of some insect-associated taxa, dermatophytes and keratinophilic species, and (2) decreased the number of cockchafer larvae in soil. Abundance of G. pannorum, Mortierella spp. + M. luteus, P. roseus, T. inflatum and T. koningii increased, at least locally. These fungi are common soft-rot wood decomposers with strong cellulolytic and xylanolytic activity, often with preferences for pine wood (Bääth \& Soderström, 1980; Blanchette et al., 1990; Eriksson et al., 1990; Rodriguez et al., 1996; Sierota \& Kwaśna, 1988, 1998; Kwaśna et al., 2000; Svarstad et al., 2000; Lumley et al., 2001; Domsch et al., 2007). The greater abundance of G. pannorum and P. roseus in foraged plots suggests their preferences also for animal-associated debris.

Abundance of Beauveria spp., M. anisopliae or $P$. carneus did not increase after sawdust amendment, probably because of their preferences for proteins rather than carbohydrates, slow growth and poor competitiveness (Hajek \& Lager, 1994; Hajek, 1997; Keller \& Zimmermann, 1989; Sun et al., 2008; Jabbour \& Barbercheck, 2009; Vega, 2009). The environmental conditions seemed to be irrelevant since they behaved similarly despite different habitat preferences (Fargues \& Robert, 1985; Bidochka et al., 1998; Klingen et al., 2002; Keller et al., 2003).

A strong decrease in abundance of Penicillium was observed in both locations, particularly after spread of sawdust and mixing it into the topsoil. This effect is commonly observed after incorporating wood into soil (authors, unpublished). It may result from antibiosis by Trichoderma (Christensen, 1969). However, since Trichoderma itself was not very abundant or was decreasing it could have resulted from successful competition from basidiomycetous wood-rot fungi, which can easily colonize the small particles of pine sawdust. Basidiomycota were not recorded with the dilution plate method used here because of their association with organic matter particles that are eliminated in the isolation procedure.

Coprophilous, dermatophytic and keratinophilic species, i.e. Cephalotrichum nanum, C. stemonitis, Ch. merdarium and S. schenckii, occurred only or mostly in plots foraged by wild boars and hares. The primary habitat of Cephalotrichum is dung. Records of C. nanum and C. stemonitis have so far been from dung of coyote, deer, rabbit and mice (Ellis \& Ellis, 1998; Chlebicki, 2008). Only Cephalotrichum microsporum (Sacc.) P.M. Kirk and C. purpureofuscum (Schwein.) S. Hughes have so far been recorded in/on dung of domestic pig (Ellis \& Ellis, 1998). Cephalotrichum nanum produces tall, slender, sharply pointed synnemata and characteristic large, distinctly rough conidia, and so its misidentification can be discounted. Chrysosporium merdarium has been observed on dung of mice, coyotes, rats and domestic pigs and their skin (Domsch et al., 2007). Sporothrix schenckii has been recorded on humans and animals as a cause of cutaneous sporotrichosis (de Hoog et al., 2000). However, the natural habitats of these fungi also include soil, com- 
post, wood, herbaceous stems, seeds, sawdust and decaying plant material (Abbott, 2000; Domsch et al., 2007; Chlebicki, 2008).

Increased populations of certain species after amendment with sawdust may increase the risk of some plant disorders and diseases. An increased population of T. inflatum increases the risk of damage to mycorrhizae (Summerbell, 1987). An increased population of species of Phoma + Pyrenochaeta under roots of seedlings increases the possibility of Phoma blight (Kliejunas et al., 1985). This disease (with symptoms of defoliation and dieback) may have contributed to the greater mortality of seedlings in foraged plots.

The presence of animal tissues and dung in Lubartów A soil increased the variety of the substrates and this increased, non-significantly, fungal diversity measured as number of species. The greater abundance but lower diversity of fungi in the sawdust-amended plots seems to have resulted from antibiosis exerted by dominants.

Whilst sawdust treatments and foraging by animals made potentially beneficial alterations to the fungal community structure in soil infested by cockchafers, there is insufficient evidence to suggest that the altered communities would contribute to significant biological control of the insects.

\section{Acknowledgements}

This project was supported by the National Centre for Research and Development through the project NCBiR NR12-0096-10

\section{References}

Abbott SP (2000) Holomorph studies of the Microascaceae (PhD Dissertation). Edmonton, Alberta, University of Alberta, pp. 1-96.

Ali SH, Alias SA, Siang HY, Smykla J, Pang KL, Guo Y \& Convey P (2013) Studies on diversity of soil microfungi in the Hornsund area, Spitsbergen. Polish Polar Research 34: 39-54.

Ali-Shtayeh MS, Mara'i ABBM \& Jamous RM (2002) Distribution, occurrence and characterization of entomopathogenic fungi in agricultural soil in the Palestinian area. Mycopathologia 156: 235-244.

Bääth E \& Söderström B (1980) Degradation of macromolecules by microfungi isolated from different podzolic soil horizons. Canadian Journal of Botany 58: 422-425.

Bandani AR, Khambay BPS, Faull L, Newton R, Deadman M \& Butt TM (2000) Production of efrapeptins by Tolypocladium species (Deuteromycotina: Hyphomycetes) and evaluation of their in- secticidal and antimicrobial properties. Mycological Research 104: 537-544.

Barron GL \& Peterson JL (1968) The genera of Hyphomycetes from the Soil. The Williams \& Wilkins Co., Baltimore.

Bidochka MJ, Kasperski JE \& Wild GAM (1998) Occurrence of the entomopathogenic fungi Metarhizium anisopliae and Beauveria bassiana in soils from temperate and near-northern habitats. Canadian Journal of Botany 76: 1198-1204.

Blanchette RA, Nilsson T, Daniel G \& Abad A (1990) Biological degradation of wood: Archaeological Wood: Properties, Chemistry, and Preservation (ed. By RM Rowell \& RJ Barbour) Advances in Chemistry Series, American Chemical Society, Washington DC, pp. 141-174.

Blum MS (1985) Fundamentals of insect physiology. John Wiley and Sons, New York.

Chlebicki A (2008) Cephalotrichum stemonitis as a biofilm inhabitant in the gold mine in Poland. Acta Mycologica 43: 67-70.

Christensen M (1969) Soil microfungi of dry to mesic conifer-hardwood forests in northern Wisconsin. Ecology 50: 9-27.

Clarkson JM \& Charnley AK (1996) New insights into the mechanisms of fungal pathogenesis in insects. Trends in Microbiology 4: 197-203.

Dolci P, Guglielmo F, Secchi F \& Ozino OI (2006) Persistence and efficacy of Beauveria brongniartii strains applied as biocontrol agents against Melolontha melotontha in the Valley of Aosta (northwest Italy). Journal of Applied Microbiology 100: 1063-72.

de Hoog GS, Guarro J, Gené J \& Figueras MJ (2000) Atlas of clinical fungi, 2nd ed. Centraalbureau voor Schimmelcultures, Utrecht, The Netherlands.

Del Frate G \& Caretta G (1990) Fungi isolated from Antarctic material. Polar Biology 11: 1-7.

Deshmukh SK (2002) Incidence of keratinophilic fungi from selected soils of Kerala state (India). Mycopathologia 156: 177-181.

Domsch KH, Gams W \& Anderson T-H (2007) Compendium of Soil Fungi. 2nd ed. IHW-Verlag, Eching, Germany.

Ellis MB \& Ellis JP (1998) Microfungi on miscellaneous substrates: An Identification Handbook. 2nd ed. The Richmond Publishing Co. Ltd., pp.1-246.

Enkerli J, Widmer F \& Keller S (2004) Long-term field persistence of Beauveria brongniartii strains applied as biocontrol agents against European cockchafer larvae in Switzerland. Biological Control 29: 115-123.

Eriksson KE, Blanchette RA \& Ander P (1990) Microbial and Enzymatic Degradation of Wood and Wood Components. Springer Verlag, Berlin. 
Fargues J \& Robert PH (1985) Persistence of conidia of 4 entomopathogenic Hyphomycetes in soil, Beauveria bassiana (Bals) Vuill Metarhizium anisopliae (Metsch) Sor, Nomuraea rileyi (F) Samson and Paecilomyces fumoso-roseus Wize, in controlled conditions. Agronomie 5: 73-80.

Grenni P, Rodríguez-Cruz MS, Herrero-Hernández E, Marín-Benito JM, Sánchez-Martín MJ \& Barra Caracciolo A (2012) Effects of wood amendments on the degradation of terbuthylazine and on soil microbial community activity in a clay loam soil. Water Air and Soil Pollution 223: 5401-5412.

Gunde-Cimerman N, Zalar P \& Jeram S (1998) Mycoflora of cave cricket Troglophilus neglectus cadavers. Mycopathologia 141: 111-114.

Hajek AE (1997) Ecology of terrestrial fungal entomopathogens. Advances in Microbial Ecology 15: 193-249.

Hajek AE \& St. Leger RJ (1994) Interactions between fungal pathogens and insect hosts. Annual Review of Entomology 39: 293-322.

Hummel RL, Walgenbach JF, Barbercheck ME, Kennedy GG, Hoyt GD \& Arellano C (2002) Effects of production practices on soil-borne entomopathogens in western North Carolina vegetable systems. Environmental Entomology 31: 84-91.

Huxham IM, Lackie AM \& McCorkindale NJ (1989) Inhibitory effects of cyclodepsipeptides destruxins from the fungus Metarhizium anisopliae on cellular immunity in insects. Journal of Insect Physiology 35: 97-105.

Jabbour R \& Barbercheck ME (2009) Soil management effects on entomopathogenic fungi during the transition to organic agriculture in a feed grain rotation. Biological Control 51: 435-443.

Keller S \& Brenner H (2005) Development of the Melolontha populations in the canton Thurgau, eastern Switzerland, over the last 50 years. IOBC/ WPRS Bulletin 28: 31- 35.

Keller S, Kessler P \& Schweizer C (2003) Distribution of insect pathogenic soil fungi in Switzerland with special reference to Beauveria brongniartii and Metarhizium anisopliae. Biocontrol 48: 307-319.

Keller S \& Zimmerman G (1989) Mycopathogens of soil insects: Insect-Fungus Interactions (ed. by $\mathrm{N}$ Wilding, NM Collins, PM Hammond \& JF Webber) Academic Press, London, UK.

Keller S \& Zimmermann G (2005) Scarabs and other soil pests in Europe: situation, perspectives and control strategies. IOBC/WPRS Bulletin 28: 9-12.

Klich MA \& Pitt JI (1992) A laboratory guide to the common Aspergillus species and their teleomorphs. Commonwealth Scientific and Industrial Research Organisation, Division of Food Processing, North Ryde, New South Wales, Australia.

Kliejunas JT, Allison JR, McCain AH \& Smith RS (1985) Phoma blight of fir and Douglas-fir seed- lings in a California nursery. Plant Disease 69: 773-775.

Klingen I, Eilenberg J \& Meadow R (2002) Effects of farming system, field margins and bait insect on the occurrence of insect pathogenic fungi in soils. Agriculture, Ecosystems and Environment 91: 191-198.

Klingen I \& Haukeland S (2006) The soil as a reservoir for natural enemies of pest insects and mites with emphasis on fungi and nematodes: An Ecological and Societal Approach to Biological Control, Progress in Biological Control. vol. 2 (ed. by J Eilenberg \& HMT Hokkanen) Springer, the Netherlands, pp. 145-211.

Kwaśna H, Bateman GL \& Ward E (2008) Determining species diversity of microfungal communities in forest tree roots by pure-culture isolation and DNA sequencing. Applied Soil Ecology 40: 44-56.

Kwaśna H, Brzeski MW \& Sierota Z (2001) Mikroorganizmy środowiska glebowego odłogujących gruntów porolnych - zmiany w zbiorowiskach grzybów i nicieni po dodaniu trocin iglastych: Drobnoustroje środowiska glebowego - aspekty fizjologiczne, biochemiczne, genetyczne (ed. by $\mathrm{H}$ Dahm \& A Pokojska) Wydawnictwo A. Marszałek, Toruń, pp. 57-66.

Kwaśna H, Sierota Z \& Bateman GL (2000) Fungal communities in fallow soil before and after amending with pine sawdust. Applied Soil Ecology 14: 177-182.

Laengle T, Pernfuss B, Seger C \& Strasser H (2005) Field efficacy evaluation of Beauveria brongniartii against Melolontha melolontha in potato cultures. Sydowia 57: 54-93.

Lakatos T \& Tóth T (2006) Biological control of European cockchafer larvae (Melolontha melolontha L.) - preliminary results. Journal of Fruit and Ornamental Plant Research 14: 73-78.

Lumley TC, Gignac LD \& Currah RS (2001) Microfungus communities of white spruce and trembling aspen logs at different stages of decay in disturbed and undisturbed sites in the boreal mixedwood region of Alberta. Canadian Journal of Botany 79: 76-92.

Luterek R \& Szmidt A (1997) Entomologia leśna $z$ zarysem ekologii owadów. Wydawnictwo Akademii Rolniczej im. A. Cieszkowskiego w Poznaniu.

Łabanowska B \& Bednarek H (2011) Efficacy of Beauveria brongniartii as Melocont in the control of the European cockchafer (Melolontha melolontha). IOBC/WPRS Bulletin 66: 179-182.

Magurran AE (1988) Ecological diversity and its measurement. Princeton University Press, Princeton, NJ.

Malinowski H (2007) Current problems of forest protection connected with the control of cock- 
chafers (Melolontha spp.). Progress in Plant Protection/Postępy w Ochronie Roślin 47: 314-322.

Marshall WA (1998) Aerial transport of keratinaceous substrate and distribution of the fungus Geomyces pannorum in Antarctic soils. Microbial Ecology 36: 212-219.

Mazet I, Hung SY \& Boucias DG (1994) Detection of toxic metabolites in the hemolymph of Beauveria bassiana infected Spodoptera exigua larvae. Experentia 50: 142-147.

Niemczyk M \& Neyko I (2009) Methods of restrictions in the number of cockchafer population in the forestry of Poland and Ukraine. Lìsìnnictvo ì agrolìsomelìoraciâ 116: 24-31.

Oltean I, Varga M, Gliga S, Florian T, Bunescu H, Bodis I \& Covaci A (2010) Monitoring Melolontha melolontha L. species in 2007, in the nursery from U.P. IV Bătrâna O.S. Toplița, Harghita Forest District. Bulletin of University of Agricultural Sciences and Veterinary Mecine Cluj-Napoca. Horticulture 67.

Petch T (1937) Notes on entomogenous fungi. Transactions of British Mycological Society 21: 34-67.

Pitt J (1979) The genus Penicillium and its teliomorphic states Eupenicillium and Talaromyces. Academic Press, New York.

Rodriguez A, Perestelo F, Carnicero A, Regalado V, Perez R, DelaFuente G \& Falcon MA (1996) Degradation of natural lignins and lignocellulosic substrates by soil-inhabiting fungi imperfecti. FEMS Microbiology Ecology 21: 213-219.

Samson RA, Evans HC \& Latge JP (1988) Atlas of entomopathogenic fungi. Springer-Verlag, New York, pp. 1-187.

Shapiro-Ilan D, Gouge D \& Koppenhöfer A (2002) Factors affecting commercial success: case studies in cotton, turf and citrus: Entomopathogenic Nematology. (ed by. R Gaugler) CABI Publishing, Oxon, New York, pp. 333-356.

Sierota Z \& Kwaśna H (1988) Effect of pine sawdust on the structure of soil fungi communities in the soils of post agricultural land. Acta Mycologica 33: $77-90$.

Sierota Z \& Kwaśna H (1998) Changes in fungal communities in abandoned farmland soil enriched with pine sawdust. Folia Forestalia Polonica, Forestry 40: 85-94.

Summerbell RC (1987) The inhibitory effect of Trichoderma species and other soil microfungi on formation of mycorrhiza by Laccaria bicolor in vitro. New Phytologist 105: 437-448.

Sun BD \& Liu XZ (2008) Occurrence and diversity of insect-associated fungi in natural soils in China. Applied Soil Ecology 39: 100-108.
Sun BD, Yu HY, Chen AJ \& Liu XZ (2008) Insect-associated fungi in soils of field crops and orchards. Crop Protection 27: 1421-1426.

Svarstad H, Bugge HC \& Dhillion SS (2000) From Norway to Novartis: cyclosporin from Tolypocladium inflatum in an open access bioprospecting regime. Biodiversity and Conservation 9: 15211541.

Svestka M (2010) Changes in the abundance of Melolontha hippocastani Fabr. and Melolontha melolontha (L.) (Coleoptera: Scarabaeidae) in the Czech Republic in the period 2003-2009. Journal of Forest Science 56: 417- 428.

Thomas MB, Watson EL \& Valverde-Garcia P (2003) Mixed infections and insect-pathogen interactions. Ecology Letters 6: 183-188.

Tischler W (1949) Grundzüge der terrestrischen Tierökologie. Braunschweig, Friedrich Vieweg und Sohn.

Toledo AV, Virla E, Humber RA, Paradell SL \& López Lastra CC (2006) First record of Clonostachys rosea (Ascomycota: Hypocreales) as an entomopathogenic fungus of Oncometopia tucumana and Sonesimia grossa (Hemiptera: Cicadellidae) in Argentina. Journal of Invertebrate Pathology 92: 7-10.

Vega FE, Goettel MS, Blackwell M, Chandler D, Jackson MA, Keller S, Koike M, Maniania NK, Monzón A, Ownley BH, Pell JK, Rangel DEN \& Roy HE (2009) Fungal entomopathogens: new insights on their ecology. Fungal Ecology 2: 149159.

Vilcinskas A, Matha V \& Gotz P (1997) Inhibition of phagocytic activity of plasmatocytes isolated from Galleria mellonella by entomogenous fungi and their secondary metabolites. Journal of Insect Physiology 43: 475-483.

Visser S, Parkinson ND \& Hassall M (1987) Fungi associated with Onychiurus subtenuis (Collembola) in an aspen woodland. Canadian Journal of Botany 65: 635-642.

Woreta D (2013) Szkodniki korzeni drzew i krzewów leśnych: Krótkoterminowa prognoza występowania ważniejszych szkodników i chorób infekcyjnych drzew leśnych w Polsce w 2013 r. Instytut Badawczy Leśnictwa, Analizy i Raporty 20: 24-27.

Woreta D (2015) Control of cockchafer Melolontha spp. grubs - a review of methods. Folia Forestalia Polonica, Series A, 57: 33-41.

Zimmermann G (2007) Review on safety of the entomopathogenic fungi Beauveria bassiana and Beauveria brongniartii. Biocontrol Science and Technology 17: 553-596. 